\title{
Antidepressant-Like Effect of Endomorphin-I and Endomorphin-2 in Mice
}

\author{
Jakub Fichna' ${ }^{1,2}$, Anna Janecka', Mariola Piestrzeniewicz', Jean Costentin², Jean-Claude do Rego*,2 \\ 'Laboratory of Biomolecular Chemistry, Faculty of Medicine, Medical University of Lodz, Lodz, Poland; 'Laboratory of Experimental \\ Neuropsychopharmacology, CNRS FRE 2735, IFRMP 23, Faculty of Medicine \& Pharmacy, University of Rouen, Rouen Cedex, France
}

\begin{abstract}
Endomorphin-I (Tyr-Pro-Trp-Phe-NH2) and endomorphin-2 (Tyr-Pro-Phe-Phe- $\mathrm{NH}_{2}$ ) are two recently isolated $\mu$-opioid selective peptides with a potent antinociceptive activity, involved in a number of physiological processes, including food intake, vasomotricity, sexual behavior, as well as neuroendocrine and cardiorespiratory functions. The neuroanatomical distribution of endomorphins prompted us to study their antidepressant activity in two animal behavioral models of depression: forced-swimming and tail-suspension tests. In both tests, the intracerebroventricular (i.c.v.) injection of either endomorphin-I or endomorphin-2 significantly decreased the duration of immobility, interpreted as an expression of 'behavioral despair', which could be related to the depression syndrome. These effects of endomorphins did not result from the stimulation of the animal motor activity. We have also demonstrated that the antidepressant-like effect of endomorphins was antagonized by the universal opioid antagonist, naloxone and the $\mu$-opioid receptor selective antagonist, $\beta$-funaltrexamine. In contrast, this effect was not antagonized by $\delta$ - and $\kappa$-opioid receptor selective antagonists, naltrindole and nor-binaltorphimine, respectively. The results of the present study demonstrate that endomorphin-I and endomorphin-2 produce potent antidepressant-like effects after i.c.v. injection in mice. We may suggest that endomorphins and the $\mu$-opioid receptors might be involved in the physiopathology of depressive disorders, and that the endomorphinergic system could serve as a novel target for the development of antidepressant drugs.

Neuropsychopharmacology (2007) 32, 8I3-821. doi: I0. I038/sj.npp. I 301 |49; published online 5 July 2006
\end{abstract}

Keywords: opioid peptide; $\mu$-opioid receptor; forced-swimming test; tail-suspension test; locomotor activity

\section{INTRODUCTION}

The discovery of the three types of opioid receptors $(\mu, \delta$, and $\kappa$ ) over 30 years ago initiated an extensive search for their selective endogenous ligands. The $\delta$-selective enkephalins were the first (Hughes et al, 1975), followed soon afterwards by the $\kappa$-selective dynorphins (Chavkin et al, 1982) and nonselective $\beta$-endorphin (Li and Chung, 1976). The $\mu$-receptor was the first opioid receptor identified in binding assays and its importance in mediating the antinociceptive action of morphine and other clinically used analgesics has been well documented (Pasternak, 1993). Yet, the search for the endogenous ligand for the $\mu$-receptor has lagged far behind the other opioid receptor types.

\footnotetext{
*Correspondence: Dr J-C do Rego, Laboratoire de Neuropsychopharmacologie Expérimentale, CNRS FRE 2735, IFRMP 23, UFR de Médecine et Pharmacie, 22, Boulevard Gambetta, 76183 Rouen Cedex, France, Tel: + 332 35|48602, Fax: + 332 35।48603,

E-mail: jean-claude.dorego@univ-rouen.fr

Received 3I January 2006; revised 28 April 2006; accepted 30 May 2006

Online publication: I June 2006 at http://www.acnp.org/citations/ Npp060 106060062/default.pdf
}

In 1997 Zadina et al (1997) synthesized and later isolated from mammalian brain two novel endogenous peptides, endomorphin-1 (Tyr-Pro-Trp-Phe- $\mathrm{NH}_{2}$ ) and endomorphin-2 (Tyr-Pro-Phe-Phe- $\mathrm{NH}_{2}$ ), which bind to the $\mu$-opioid receptor with extremely high affinity and selectivity. Radioimmunological and immunocytochemical analyses revealed that both endomorphins are densely distributed throughout the central nervous system, near neurons expressing the $\mu$-opioid receptors (Martin-Schild et al, 1999; Zadina et al, 1999; Zadina, 2002). Endomorphins were found in the limbic system (septum, nucleus accumbens, amygdala), thalamic nuclei, locus coeruleus, and in the brain stem (Schreff et al, 1998; Martin-Schild et al, 1999; Zadina, 2002). Some of these regions are known to be involved in mood disorders, such as anxiety and depression (Drevets and Raichle, 1992; Drevets et al, 1992; Drevets, 1998; Sheline, 2000). It has also been demonstrated that endomorphins and the $\mu$-opioid receptors are present in the brain regions containing monoamine neurotransmitters (serotonin, dopamine, and noradrenaline), which play a key role in the physiopathology of depressive disorders. In fact, endomorphins have been shown to modulate serotoninergic (Chen et al, 2001; Tao and Auerbach, 2002; Hung et al, 2003), dopaminergic (Chen et al, 2001; Ukai and Lin, 2002; 
Bujdoso et al, 2003; Huang et al, 2004), and noradrenergic (Chen et al, 2001; Al-Khrasani et al, 2003; Hung et al, 2003) transmissions.

The possible role of endogenous opioid peptides in depression is supported by neurochemical and neurobehavioral findings (Belluzi and Stein, 1977; De Witte et al, 1989). However, little is known about the antidepressant activity of endomorphins. The aim of the present study was to investigate the antidepressant effects of endomorphin-1 and endomorphin-2 after intracerebroventricular (i.c.v.) administration in mice in two behavioral models: forced-swimming and the tail-suspension tests (TST). We have also examined the effect of both endomorphins on the locomotor activity, which might influence nonspecifically the animal responses in these tests.

\section{MATERIALS AND METHODS}

\section{Animals}

Male Swiss albino CD1 mice (IFFA-CREDO/Charles River, Saint-Germain sur L'Arbresle, France), weighing 20-22 g, were used throughout the study. The animals were housed 20 per Makrolon cage (L: 40, W: $25, \mathrm{H}: 18 \mathrm{~cm}$ ), with free access to standard semisynthetic laboratory diet (UAR, Villemoisson sur Orge, France) and tap water ad libitum, under controlled environmental conditions (ventilated room, temperature $22 \pm 1^{\circ} \mathrm{C}, 12 \mathrm{~h}$ light $/ 12 \mathrm{~h}$ dark cycle, lights on between 07:00 and 19:00 hours). All experiments were carried out between 09:00 and 18:00 hours, unless otherwise stated, in test rooms adjacent to the animal rooms. The experiments were performed according to the European Communities Council Directive from 24 November 1986 (86/609/EEC) and were conducted by authorized investigators. Mice were tested only once and killed immediately thereafter by decapitation.

\section{Chemicals}

Peptides were synthesized by standard solid-phase procedures as described before (Fichna et al, 2004), using techniques for Fmoc-protected amino acids on MBHA Rink peptide resin (100-200 mesh, $0.8 \mathrm{mM} / \mathrm{g}$, Novabiochem). $20 \%$ Piperidine in dimethylformamide was used for deprotection of Fmoc-groups and 2-(1H-benzotriazol-1yl)-1,1,3,3-tetramethyluronium tetrafluoroborate (TBTU) was employed to facilitate coupling. Simultaneous deprotection and cleavage from the resin was accomplished by treatment with trifluoroacetic acid: triisopropylsilane: water (95: 2.5: 2.5) for $3 \mathrm{~h}$ at room temperature. Crude peptides were purified by RP HPLC on a Vydac $\mathrm{C}_{18}$ column $(1 \times 25 \mathrm{~cm})$ using the solvent system of $0.1 \%$ TFA in water (A) $/ 80 \%$ acetonitrile in water containing $0.1 \%$ TFA (B) and a linear gradient. Calculated values for protonated molecular ions were in agreement with those obtained using $\mathrm{FAB}$ mass spectrometry.

Opioid receptor antagonists, naloxone hydrochloride, $\beta$-funaltrexamine hydrochloride, naltrindole dihydrochloride, and nor-binaltorphimine hydrochloride were purchased from Sigma-Aldrich (Saint Quentin Fallavier, France). Peptides and opioid receptor antagonists were dissolved in sterile saline $(0.9 \% \mathrm{NaCl})$ just before treatment.

\section{Intracerebroventricular Injections}

i.c.v. injections $(10 \mu 1 /$ mouse) were performed in the left brain ventricle of manually immobilized mice, with a Hamilton microsyringe ( $50 \mu$ l, Hamilton, Bonaduz, Switzerland) connected to a needle (length: $3.5 \mathrm{~mm}$, diameter: $0.5 \mathrm{~mm}$ ), as described elsewhere (Fichna et al, 2004). I.c.v. injections were performed by an experienced investigator, who frequently controlled the regularity and the success of injections using a methylene blue dye and who observed, after killing and frontal brain sectioning that the injection was successful in more than $95 \%$ of trials. It was also verified in several animals, after killing, that the mark of the needle puncture on the parietal bone was located at least $1.5 \mathrm{~mm}$ behind the bregma and at least $2.5 \mathrm{~mm}$ before the lambda, with laterality between 1 and $2 \mathrm{~mm}$ relative to the brain median line. This corresponds to stereotaxic coordinates of the left lateral ventricle in Lehmann's atlas for mice (Lehmann, 1974): anteriority $2.95-4.15 \mathrm{~mm}$, laterality $0.95-$ $2 \mathrm{~mm}$, and depth 3-4.5 mm. The i.c.v. injection method was approved by the Regional Ethical Committee for Animal Experimentation (Normandy; no. N/10-04-04-12).

\section{Forced-Swimming Test}

The forced-swimming test was essentially similar to that described by Porsolt et al (1977). The apparatus with larger Plexiglas cylinders $(14 \mathrm{~cm}$ in diameter instead of $10 \mathrm{~cm})$, similar to that employed by Semba and Takahashi (1988) and Do-Rego et al $(2002,2005)$ was used, since Sunal et al (1994) demonstrated that a cylinder with a larger diameter decreases the number of false positive responses. The apparatus consisted of two Plexiglas cylinders $(20 \mathrm{~cm}$ height, $14 \mathrm{~cm}$ internal diameter), placed side-by-side in a Makrolon cage (L: $38, \mathrm{~W}: 24, \mathrm{H}: 18 \mathrm{~cm}$ ) and separated by an opaque screen. The Makrolon cage was filled with water $\left(22 \pm 1^{\circ} \mathrm{C}\right)$ to a height of $12 \mathrm{~cm}$, instead of $6 \mathrm{~cm}$ suggested by Porsolt et al (1977), since, according to Petit-Demouliere et al (2005), the depth of water is an important parameter to be considered as mice should not sense a limit under the level of water. The behavior of mice would indeed be altered if their tails touch the bottom of the cylinder.

At $15 \mathrm{~min}$ before the test the animals were isolated in small individual cages (L: 25, W: $9, \mathrm{H}: 8 \mathrm{~cm}$ ) at an ambient temperature $\left(22 \pm 1^{\circ} \mathrm{C}\right)$. After i.c.v. injection two mice were tested simultaneously for a 6-min period. Total duration of immobility was measured during three consecutive periods of 2 min, each using an automated image analysis system (Videotrack MV 45). The method was approved by the Regional Ethical Committee for Animal Experimentation (Normandy; no. N/09-04-04-11).

\section{Tail-Suspension Test}

The TST was performed as described previously (Steru et al, 1987), using a computerized device (ITEMATIC-TST) developed by ITEMLabo (Le Kremlin-Bicêtre, France). At $15 \mathrm{~min}$ before the test the animals were isolated in small individual cages (L: 25, W: $9, \mathrm{H}: 8 \mathrm{~cm}$ ) at an ambient temperature $\left(22 \pm 1^{\circ} \mathrm{C}\right)$. After i.c.v. injection mice were suspended by tail, using an adhesive Scotch tape, to a hook connected to a strain gauge, which detected all movements 
of an animal. The signals were transmitted to a central unit, which calculated the total duration of animal immobility over $6 \mathrm{~min}$ of the test. Six animals were tested simultaneously. The method was approved by the Regional Ethical Committee for Animal Experimentation (Normandy; no. N/14-04-04-16).

\section{Measurement of Locomotor Activity}

Locomotor activity was assessed automatically in a Digiscan actimeter (Omnitech Electronics Inc., Columbus, OH, USA), which monitored horizontal displacements and vertical movements. The animals were placed individually in $20 \times 20 \times$ $30 \mathrm{~cm}$ compartments, in a dimly illuminated and quiet room. The responses were expressed as the number of crossed beams by mouse during four consecutive 15 min periods.

\section{Statistical Analysis}

The data are expressed as means \pm SEM. Differences between groups were assessed by one-way analysis of variance (ANOVA) followed by a post hoc multiple comparison Student-Newman-Keuls test. Antagonist effects in the combination experiments were analyzed using two-way analysis of variance (ANOVA) and a post hoc multiple
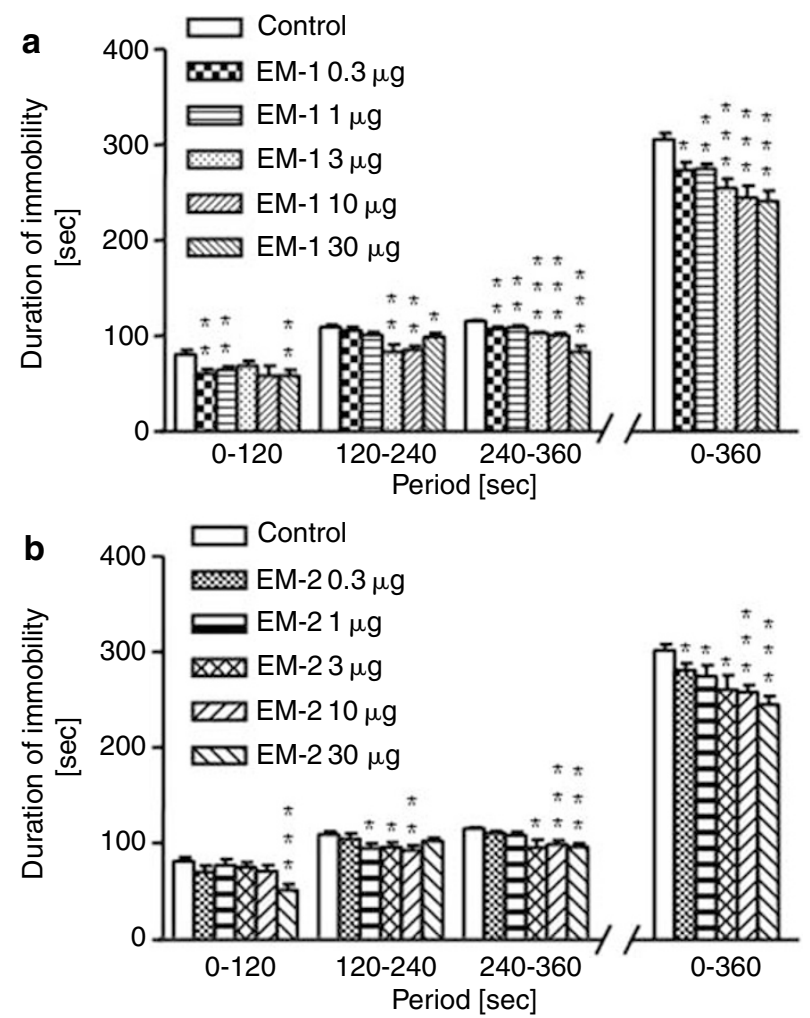

Figure I Dose-response effect of endomorphin-I and endomorphin-2 on the forced-swimming test. Mice were injected i.c.v. with saline or peptides $(0.3-30 \mu \mathrm{g} / \mathrm{animal})$ and submitted to the swimming test $10 \mathrm{~min}$ after the injection. The duration of immobility was measured during a 6-min period (three consecutive periods of $2 \mathrm{~min}$ each). Data represent mean \pm SEM of 10 mice per group. $* p<0.05$; $* * 0<0.0$; ${ }^{*} * * * 0.00$ I, as compared to respective control by using one-way ANOVA followed by the Student-Newman-Keuls' test. comparison Student-Newman-Keuls test was used for multiple comparisons between groups. A probability level of 0.05 or lower was considered as statistically significant.

\section{RESULTS}

\section{Dose-Response Effect of Endomorphins on the Forced-Swimming and TST}

In the present study, the activity of endomorphin-1 and endomorphin-2 was examined in two animal behavioral models of depression: forced-swimming and TST, as well as in locomotor activity assay. The results of the forcedswimming test, performed $10 \mathrm{~min}$ after i.c.v. administration of endomorphin-1 and endomorphin-2, in a dose range $0.3-30 \mu \mathrm{g} /$ mouse, are shown in Figure 1. Both peptides decreased, in a dose-dependent manner, the duration of immobility in all three time periods of the test and during the total time of experiment $(0-360 \mathrm{~s})$. In the total time of experiment, endomorphins produced a significant effect $(p<0.05-0.001)$ in all tested doses.

In the TST, the i.c.v. injection of endomorphin-1 or endomorphin-2 $(0.3-30 \mu \mathrm{g} /$ mouse $) 10 \mathrm{~min}$ before the assay reduced, in a dose-dependent manner, the duration of animal immobility (Figure 2). For both peptides, the signi-
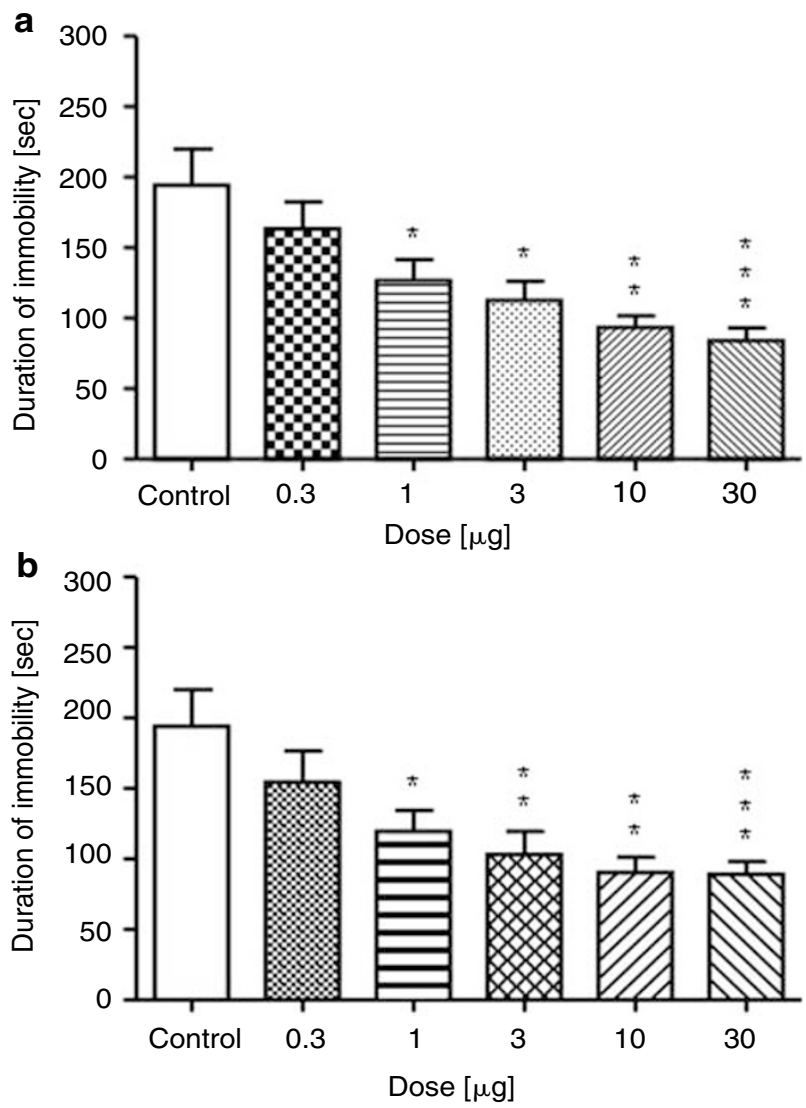

Figure 2 Dose-response effect of endomorphin-I and endomorphin-2 on the TST. Mice were injected i.c.v. with saline or peptides $(0.3-30 \mu \mathrm{g} /$ animal) and submitted to the test 10 min after the injection. The duration of immobility was measured during a 6-min period. Data represent mean \pm SEM of 10 mice per group. ${ }^{*} p<0.05$; $* *$ * $p<0.0$ I; $* * * * 0.00$ I, as compared to respective control by using one-way ANOVA followed by the Student-Newman-Keuls' test. 
ficant effect $(p<0.05-0.001)$ was observed at the doses ranging from 1 to $30 \mu \mathrm{g} /$ mouse.

\section{Time-Course of the Effect of Endomorphins on the Forced-Swimming Test}

The time-response curves for endomorphin-1 and endomorphin-2 $(10 \mu \mathrm{g} / \mathrm{animal}$, i.c.v. $)$ in the forced-swimming test are shown in Figure 3. The effects of endomorphins were measured $10,15,20,30,45$, or 60 min after administration. The inhibitory effect of endomorphin-1 was only observed 10 and $15 \mathrm{~min}$ after injection. It was significant $(p<0.05-0.001)$ in the second (120-240 s) and third (240$360 \mathrm{~s})$ period of the test and during the total time of experiment. Endomorphin-2 produced a significant effect $(p<0.05-0.01)$ only $10 \mathrm{~min}$ after administration.
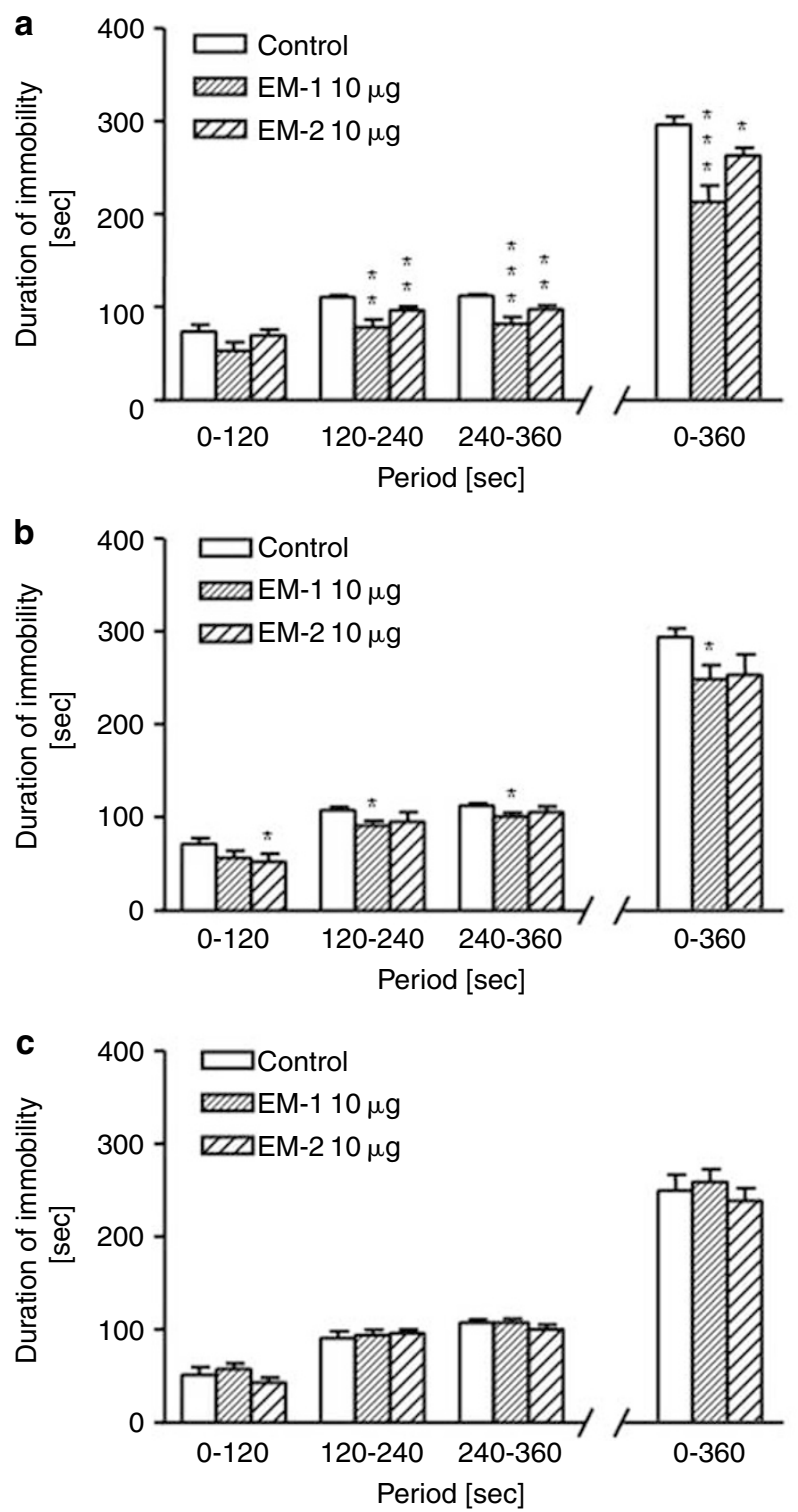

\section{Dose-Response Effect of Endomorphins on Locomotor Activity}

The influence of the i.c.v. administration of endomorphin-1 and endomorphin-2 on locomotor activity was measured over four consecutive periods of $15 \mathrm{~min}$ each (Figure 4). The peptides did not modify the horizontal locomotor activity in any of the time periods of the test (Figure $4 \mathrm{a}$ and $\mathrm{b}$ for endomorphin-1 and endomorphin-2, respectively). Endomorphin-1, at the highest dose tested ( $30 \mu \mathrm{g} / \mathrm{mouse})$, produced a significant inhibition $(p<0.05)$ of the vertical locomotor activity in the first time period of the assay (0-15 min, Figure $4 \mathrm{c})$. On the contrary, endomorphin-2, at the lowest dose $(0.3 \mu \mathrm{g} / \mathrm{animal})$, significantly $(p<0.05)$ diminished vertical locomotor activity in the first $(0-15 \mathrm{~min})$ and third (45-60 min) time periods of the test, and at the dose of
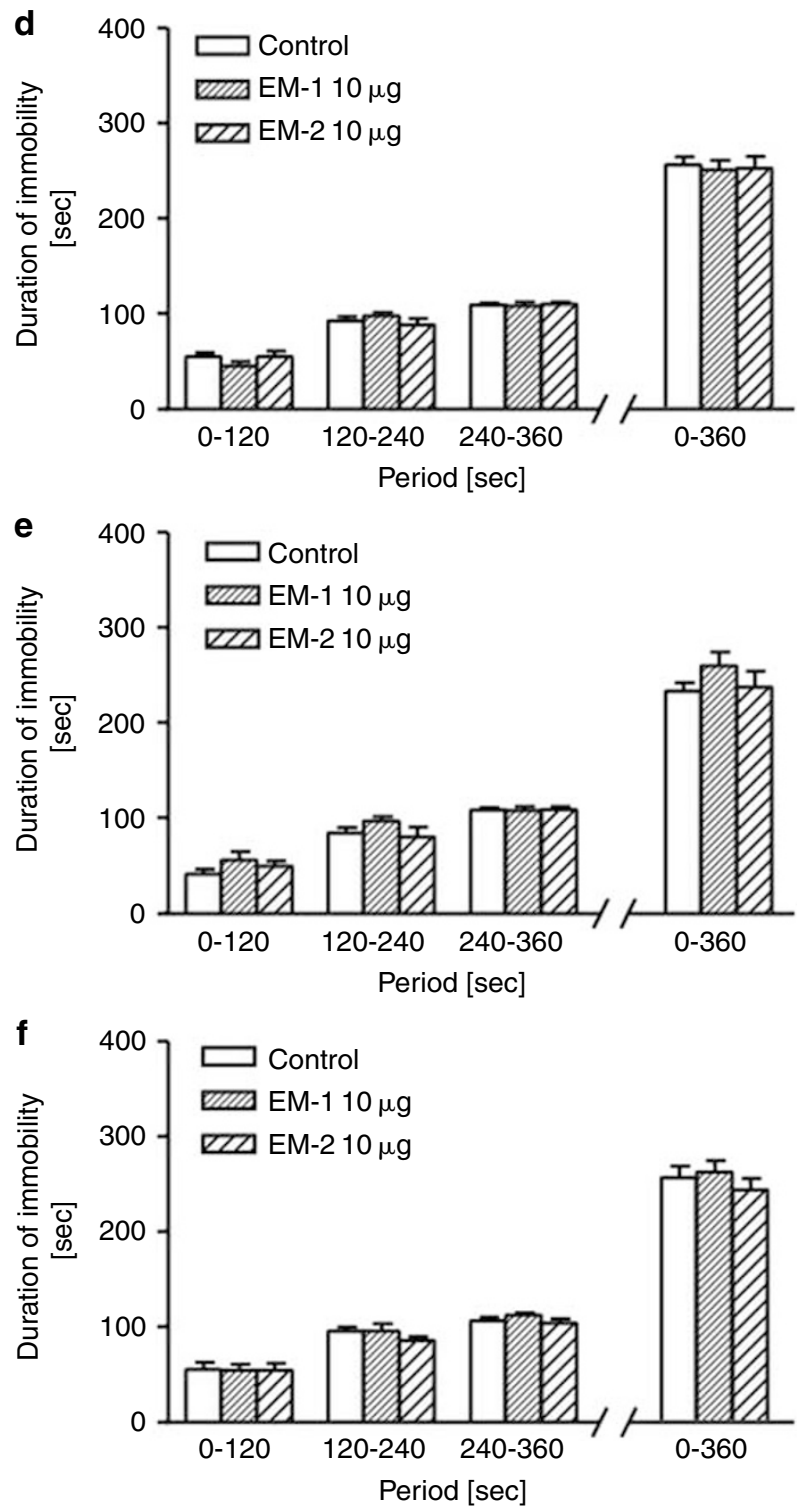

Figure 3 Time-course of the effect of endomorphin-I and endomorphin-2 on the forced-swimming test. Mice were injected i.c.v. with saline or peptides ( $10 \mu \mathrm{g} / \mathrm{animal}$ ) and submitted to the swimming test 10 (a), 15 (b), 20 (c), 30 (d), 45 (e), or 60 min (f) after the injection. The duration of immobility was measured during a 6 -min period (three consecutive periods of 2 min each). Data represent mean \pm SEM of 10 mice per group. * $p<0.05$; *** $<0.0$ I; **** $p<0.00$ I, as compared to respective control by using one-way ANOVA followed by the Student-Newman-Keuls' test. 

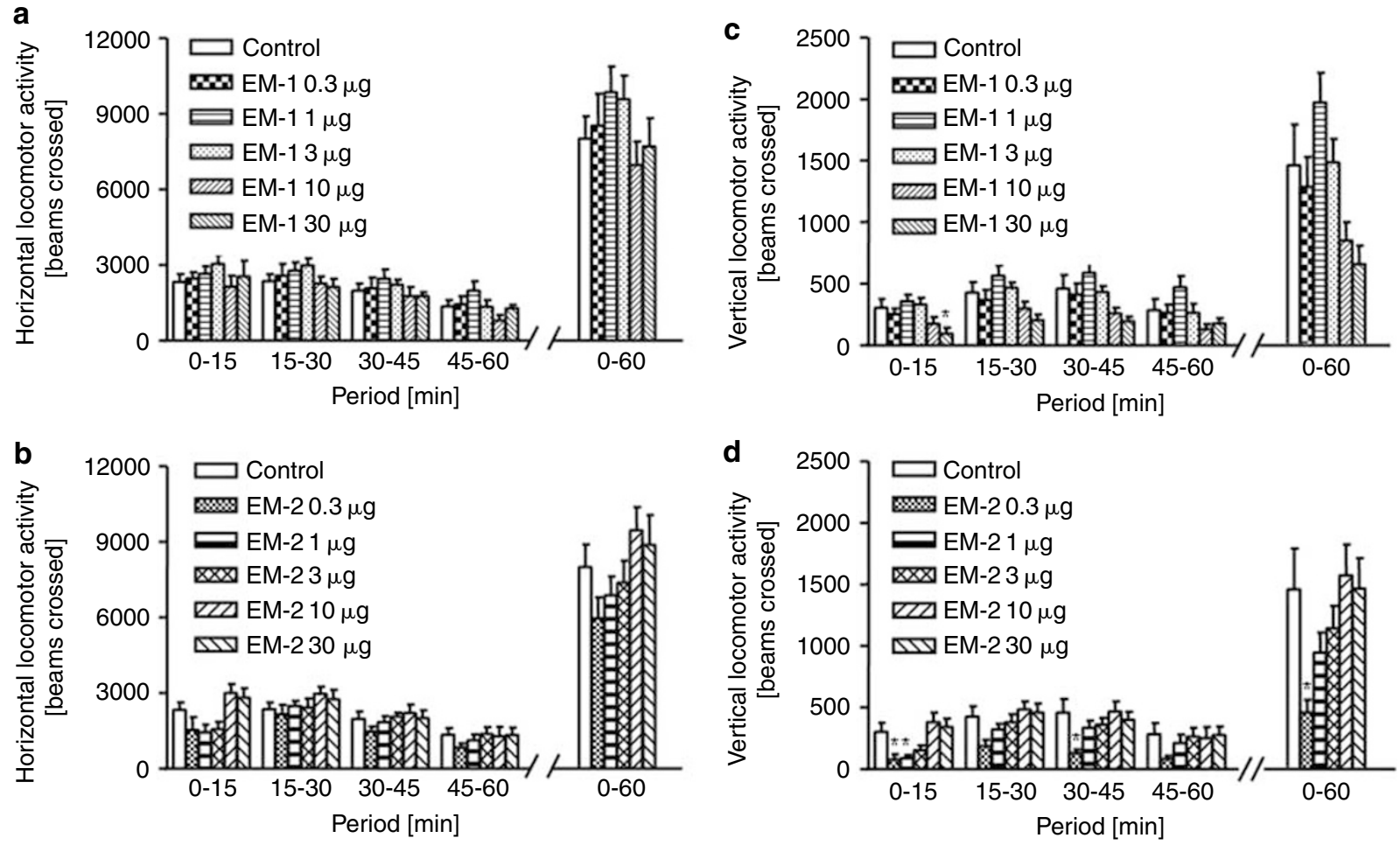

Figure 4 Dose-response effect of endomorphin-I and endomorphin-2 on horizontal (a and b, respectively) and vertical (c and d, respectively) locomotor activity. Mice were injected i.c.v. with saline or peptides $(0.3-30 \mu \mathrm{g} / \mathrm{animal})$ and placed in the actimeters immediately after the injection. Horizontal displacements and vertical movements were measured for four consecutive periods of I $5 \mathrm{~min}$. Data represent mean \pm SEM of I 0 mice per group. * $p<0.05$, as compared to respective control by using one-way ANOVA followed by the Student-Newman-Keuls' test.

$1 \mu \mathrm{g} /$ animal in the first $(0-15 \mathrm{~min})$ time period of the test (Figure 4d).

\section{Comparison of the Antagonist Properties of Naloxone on the Endomorphin-Induced Effect on the Forced-Swimming Test}

The hypothesis that the inhibitory effect of endomorphins on the forced-swimming test is mediated through the opioid receptors was also examined. The duration of animal immobility was measured after a concomitant i.c.v. administration of endomorphin-1 or endomorphin-2 $(3 \mu \mathrm{g} / \mathrm{ani}$ mal) and the universal opioid receptor antagonist naloxone ( $5 \mu \mathrm{g} /$ animal) and compared to that produced by endomorphins injected alone. We observed a significant inhibitory effect of i.c.v. administered naloxone $(p<0.05-0.01)$ on endomorphins-induced behavior in all three time periods of the assay (Figure $5 \mathrm{a}$ and $\mathrm{b}$ ). The pretreatment with naloxone, injected intraperitoneally (i.p.) at the dose of $1 \mathrm{mg} / \mathrm{kg}$ animal $30 \mathrm{~min}$ before the i.c.v. injection of endomorphins, also produced a significant antagonist effect $(p<0.05-0.001$, Figure $5 c$ and $d)$. Naloxone administered alone had no effect on the time of animal immobility in the forced-swimming test in mice.

\section{Selective Opioid Receptor Antagonists on the Endomorphin-Induced Effect on the Forced-Swimming Test}

In order to examine which of the receptor types mediates the endomorphin-induced effect on the forced-swimming test, we have measured the time of animal immobility after a concomitant i.c.v. administration of endomorphin-1 or

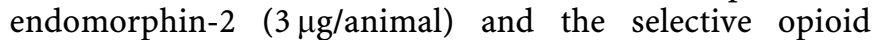
receptor antagonists. We observed a significant inhibitory effect $(p<0.05-0.001)$ of a selective $\mu$-opioid receptor antagonist $\beta$-funaltrexamine ( $1 \mu \mathrm{g} / \mathrm{animal}$, i.c.v.) on endomorphin-induced behavior in all three time periods of the assay (Figure 6). The coadministration of $\delta$-selective antagonist naltrindole $(1 \mu \mathrm{g} / \mathrm{animal})$ and $\kappa$-selective antagonist nor-binaltorphimine $(5 \mu \mathrm{g} / \mathrm{animal})$ with endomorphins $(3 \mu \mathrm{g} /$ animal) produced no significant effect (Figures 7 and 8 , respectively). The opioid antagonists administered alone had no effect on the time of animal immobility. These results clearly show that the endomorphin-induced effect on the forced-swimming test is mediated by the $\mu$-opioid receptors.

\section{DISCUSSION}

The results of the present study suggest that endomorphin-1 and endomorphin-2 produce an antidepressant-like effect in the forced-swimming and the TST after i.c.v. injection in mice. This is the first report on the involvement of endomorphinergic system in physiopathology of depression. In most of the behavioral models of depression animals are exposed to mildly aversive situations, from which there is no possibility to escape and which induce recognizable behavioral changes. In both, the forcedswimming test and the TST, a prolonged exposure to aversive situations induces immobility, interpreted as an expression of behavioral despair, which could be related to 

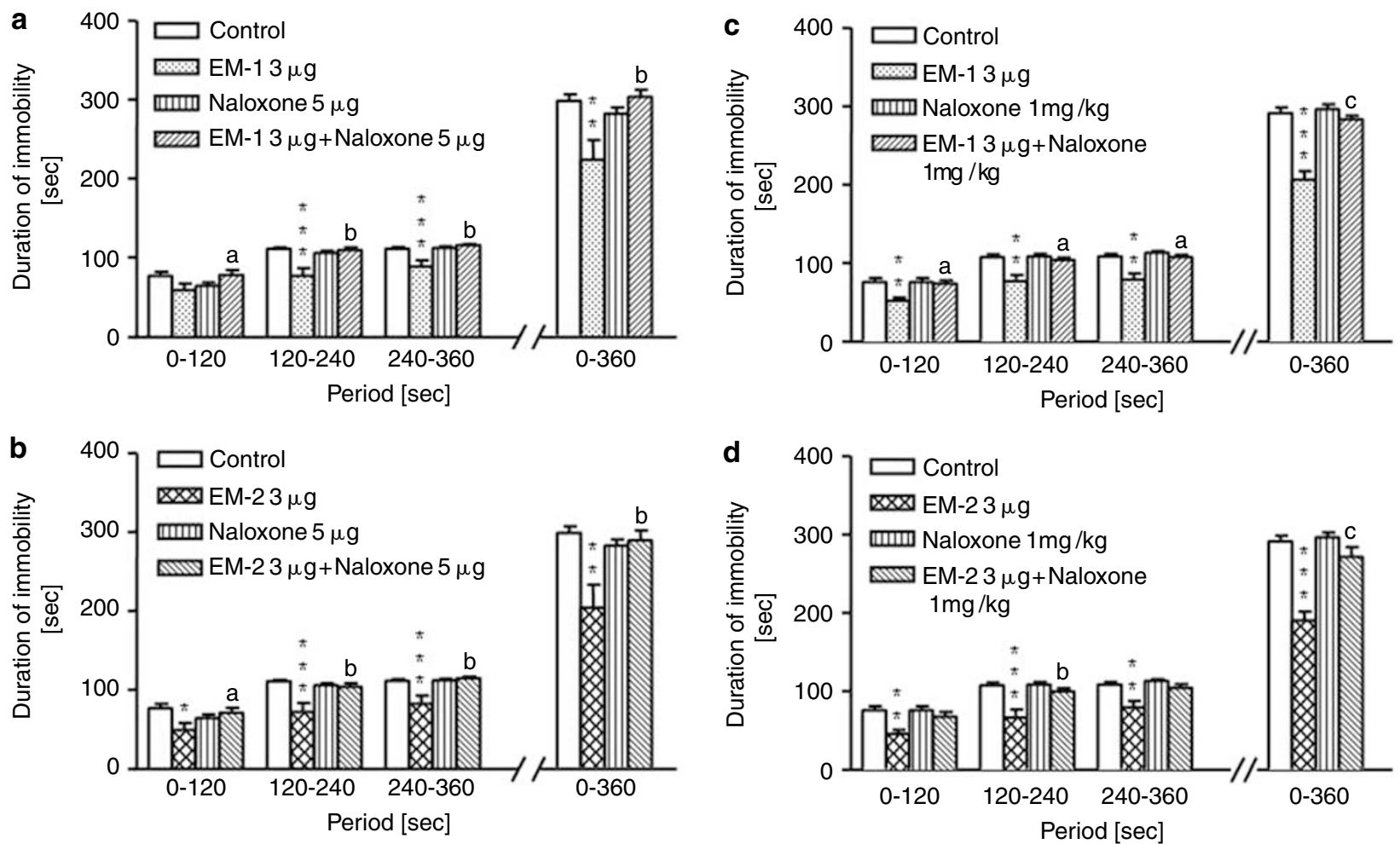

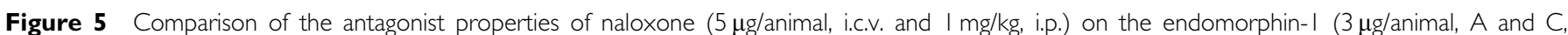
respectively) and endomorphin-2 ( $3 \mu \mathrm{g} /$ animal, $\mathrm{B}$ and $\mathrm{D}$, respectively)-induced effect on the forced-swimming test. The duration of immobility was measured during a 6-min period (three consecutive periods of 2 min each). Data represent mean \pm SEM of I 0 mice per group. $* p<0.05$; $* * * 0.01$; $* * * *<<0.00$ I, as compared to respective control by using two-way ANOVA followed by the Student-Newman-Keuls' test. A two-way ANOVA analysis revealed a significant interaction between: naloxone $(5 \mu \mathrm{g} /$ animal, i.c.v. $)$ and endomorphin- I: $F(I, 44)=6.327 ;{ }^{a} p<0.05(0-120 \mathrm{~s}), F(I, 44)=\mid I .775 ;{ }^{b} p<0.01$ I $(I 20-$ $240 \mathrm{~s}), \quad F(I, 44)=9.102 ;{ }^{b} p<0.01 \quad(240-360 \mathrm{~s}), \quad F(I, 44)=10.850 ;{ }^{b}<<0.01 \quad(0-360$ s); between naloxone $(5 \mu g / a n i m a l$, i.c.v. $)$ and endomorphin-2: $F(I, 44)=6.800 ;{ }^{a} p<0.05(0-120 s), F(I, 44)=7.836 ;{ }^{b} p<0.0 I \quad(I 20-240 s), F(I, 44)=8.063 ;{ }^{b} p<0.0 I \quad(240-360 s), F(I, 44)=8.962 ;{ }^{b} p<0.0 I(0-360 s) ;$ between naloxone (I mg/kg, i.p.) and endomorphin-I: $F(I, 44)=4.629 ;{ }^{a} p<0.05(0-120 \mathrm{~s}), F(I, 44)=6.559 ;{ }^{a} p<0.05(I 20-240 \mathrm{~s}), F(I, 44)=6.474 ;{ }^{a} p<0.05$

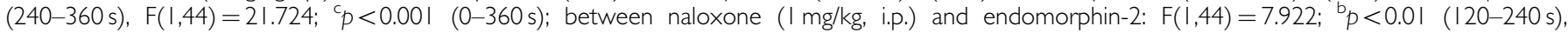
$F(I, 44)=15.038 ; c^{c}<<0.00 \mid$ (0-360s).

the depression syndrome (Porsolt et al, 1977; Steru et al, 1987). These tests are quite sensitive and relatively specific to all major classes of antidepressant agents, including tricyclics, serotonin-specific reuptake inhibitors, and monoamine oxidase inhibitors.

In our study, endomorphin-1 and endomorphin-2 significantly reduced the time of animal immobility in the forced-swimming test and the TST. These effects were dosedependent and short-lasting; a significant response was observed only 10 and $15 \mathrm{~min}$ after i.c.v. administration. The magnitude of the effect induced by endomorphins was comparable to that observed after the treatment with wellknown antidepressants and the compounds with potential antidepressant-like activity, both in the forced-swimming test (Petit-Demouliere et al, 2005) and the TST (Cryan et al, 2005).

Contrarily to other $\mu$-opioid receptor agonists (Babbini and Davis, 1972), the antidepressant-like effect of endomorphins did not result from the stimulation of the animal motor activity, since the peptides did not increase the horizontal locomotor activity evaluated in a new environment. We have even observed a minor tendency to decrease the vertical movements. This is in good agreement with the classical observations that antidepressants reduce the immobility in the forced-swimming test at the doses that do not cause the stimulation of locomotion (Porsolt et al, 1977) or even tend to decrease locomotor activity (DuterteBoucher et al, 1988; Bourin, 1990). The decrease of vertical locomotor activity after i.c.v. administration of endomorphin-2 was independent of its antidepressant-like effect, since it was observed for much longer time after peptide injection ( 45 and $15 \mathrm{~min}$, respectively). It should be pointed out that in the earlier studies endomorphin-2, at low doses $(0.25$ and $0.5 \mu \mathrm{g} / \mathrm{animal}$, i.c.v. $)$, significantly stimulated locomotor activity in mice (Bujdoso et al, 2001). However, a different modality of testing (open field box) was used. Furthermore, a shorter duration of the assay $(3 \mathrm{~min})$ and a much longer time period ( $30 \mathrm{~min}$ ) between peptide administration and beginning of the assay were applied.

Here, we also demonstrated that both naloxone, a reference opioid receptor antagonist with a relatively high affinity towards the $\mu$-opioid receptors and $\beta$-funaltrexamine, a selective $\mu$-opioid receptor antagonist, significantly antagonized the antidepressant-like effect of endomorphins. In contrast, neither naltrindole, a selective $\delta$-opioid receptor antagonist, nor nor-binaltorphimine, a selective $\kappa$-opioid receptor antagonist, were able to block the antidepressantlike effect of endomorphins. These results indicate that the 

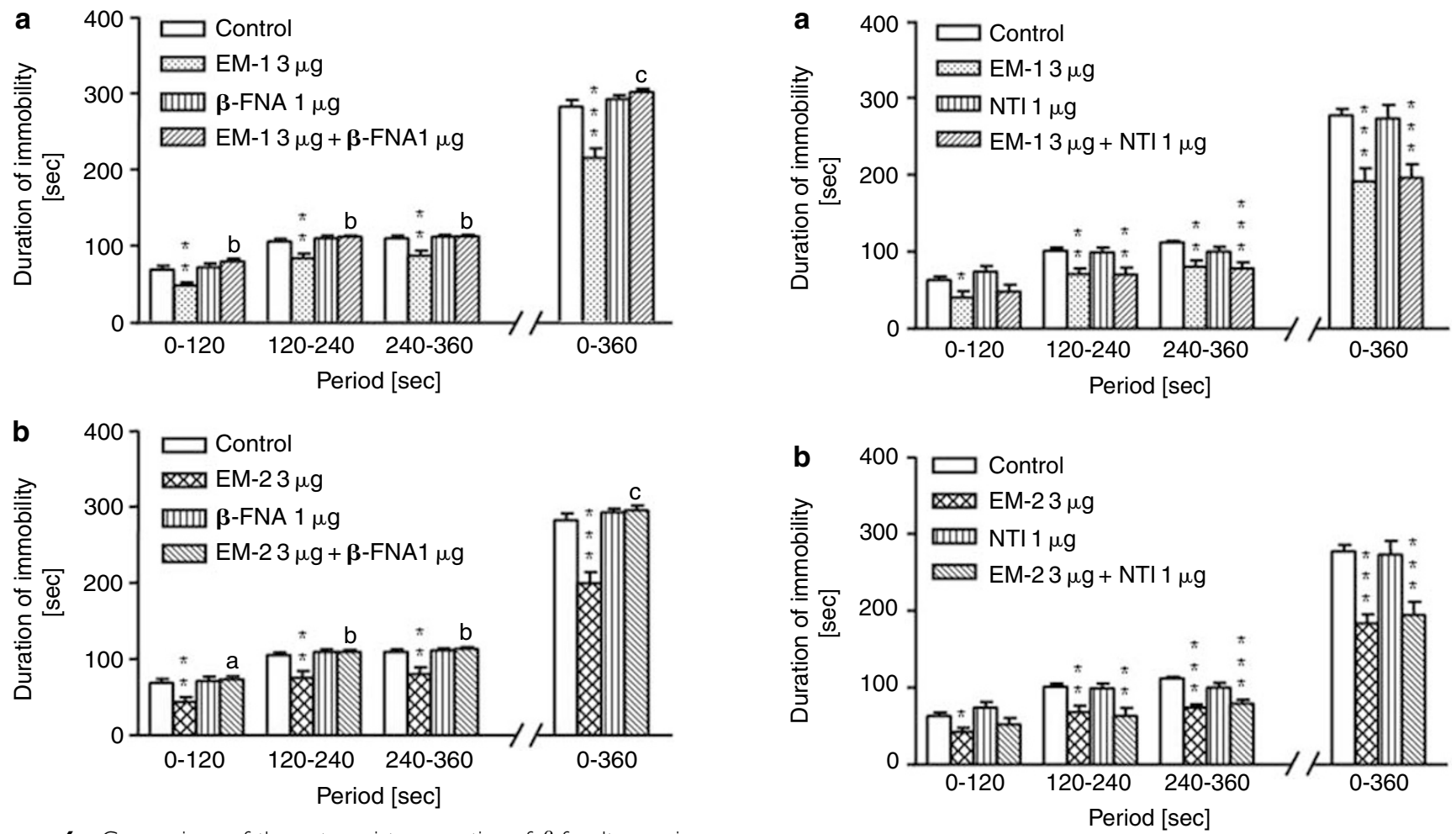

Figure 6 Comparison of the antagonist properties of $\beta$-funaltrexamine $(\beta$-FNA, I $\mu \mathrm{g} / \mathrm{animal})$ on the endomorphin- I $(3 \mu \mathrm{g} / \mathrm{animal}, \mathrm{a})$ and endomorphin-2 ( $3 \mu \mathrm{g} / \mathrm{animal}, \mathrm{b})$-induced effect on the forced-swimming test. Mice were injected i.c.v. and submitted to the swimming test $10 \mathrm{~min}$ after the injection. The duration of immobility was measured during a 6 -min period (three consecutive periods of $2 \mathrm{~min}$ each). Data represent mean \pm SEM of 10 mice per group. $* *$ $p<0.01$; **** $p<0.00$ I, as compared to respective control by using two-way ANOVA followed by the StudentNewman-Keuls' test. A two-way ANOVA analysis revealed a significant interaction between: $\beta$-funaltrexamine and endomorphin-I: $\mathrm{F}(\mathrm{I}, 36)=$ 8.999; ${ }^{b} p<0.01$ ( $\left.0-120 \mathrm{~s}\right), F(1,36)=7.978 ;{ }^{b} p<0.01$ (I $\left.20-240 \mathrm{~s}\right), F(1,36)$ $=8.139 ;{ }^{b} p<0.0 I \quad(240-360 \mathrm{~s}), F(I, 36)=20.759 ;{ }^{c} p<0.00 I \quad(0-360 s)$; between $\beta$-funaltrexamine and endomorphin-2: $F(1,36)=5.636 ;{ }^{a} p<0.05$ $(0-120 \mathrm{~s}), \quad F(I, 36)=8.052 ; \quad b_{p}<0.01 \quad(I 20-240 s), \quad F(I, 36)=8.702$; ${ }^{b} p<0.01$ (240-360s), $F(I, 36)=20.728 ;{ }^{c} p<0.001$ ( $\left.0-360 s\right)$.

effect of endomorphins is mediated, in great part, through central $\mu$-opioid receptors. Endomorphin-1 and endomorphin-2 were shown to possess a high affinity and an extreme selectivity for the $\mu$-opioid receptors and most of their effects are mediated through the $\mu$-binding sites (Champion et al, 1997; Asakawa et al, 1998; Czapla et al, 2000; Fichna et al, 2005). It has also been demonstrated that there is a significant association between the $\mu$-opioid receptors and the etiology of depressive disorders. High concentration of the $\mu$-opioid peptides and receptors was observed in the limbic areas involved in the regulation of mood (Mansour et al, 1988). Moreover, the $\mu$-opioid receptor-knockout mice appear to have an altered emotional state that is consistent with a depressed mood (Filliol et al, 2000). Therefore, we could suggest that endomorphins produce their antidepressant-like effect by the activation of the $\mu$-opioid receptors. This observation is in good agreement with the previous studies, showing that a wide variety of the $\mu$-opioid receptor agonists, including $\beta$-endorphin and buprenorphine, possess antidepressant-like behavioral effects (Mansour et al, 1988; Darko et al, 1992; Bodkin et al, 1995; Tejedor-Real

Figure 7 Comparison of the antagonist properties of naltrindole (NTI, I $\mu \mathrm{g} / \mathrm{animal})$ on the endomorphin- I (3 $\mu \mathrm{g} / \mathrm{animal}, \mathrm{a})$ and endomorphin-2 ( $3 \mu \mathrm{g} / \mathrm{animal}, \mathrm{b})$-induced effect on the forced-swimming test. Mice were injected i.c.v. and submitted to the swimming test 10 min after the injection. The duration of immobility was measured during a 6-min period (three consecutive periods of 2 min each). Data represent mean \pm SEM of 10 mice per group. $* p<0.05$; ** $p<0.01$; **** $p<0.00$ I, as compared to respective control by using two-way ANOVA followed by the Student-NewmanKeuls' test.

et al, 1995; Besson et al, 1996; Stoll and Rueter, 1999; Vilpoux et al, 2002) and that morphine, an alkaloid opiate with substantial affinity to the $\mu$-opioid receptors, produces a significant antidepressant effect in the forced-swimming test after subcutaneous injections (Eschalier et al, 1987).

Endomorphins and the $\mu$-opioid receptors are localized in the brain regions involved in the physiopathology of depression, such as the limbic system (septum, nucleus accumbens, amygdala), thalamic nuclei, locus coeruleus, and some regions of brain stem (Schreff et al, 1998; MartinSchild et al, 1999; Zadina, 2002). These regions are known to contain neurotransmitter-like monoamines (serotonin, dopamine and noradrenaline), which play an important role in the etiology of depressive disorders. Numerous earlier studies have shown that endomorphins modulate serotoninergic (Chen et al, 2001; Tao and Auerbach, 2002; Hung et al, 2003), dopaminergic (Chen et al, 2001; Ukai and Lin, 2002; Bujdoso et al, 2003; Huang et al, 2004) and noradrenergic (Chen et al, 2001; Al-Khrasani et al, 2003; Hung et al, 2003) transmission. We could therefore suggest that the antidepressant-like effect of endomorphin-1 and endomorphin-2 might be mediated by the neurotransmitterlike monoamines.

In conclusion, the present study demonstrates a novel behavioral effect of two $\mu$-receptor selective endogenous opioid peptides, endomorphin-1, and endomorpin-2. The 

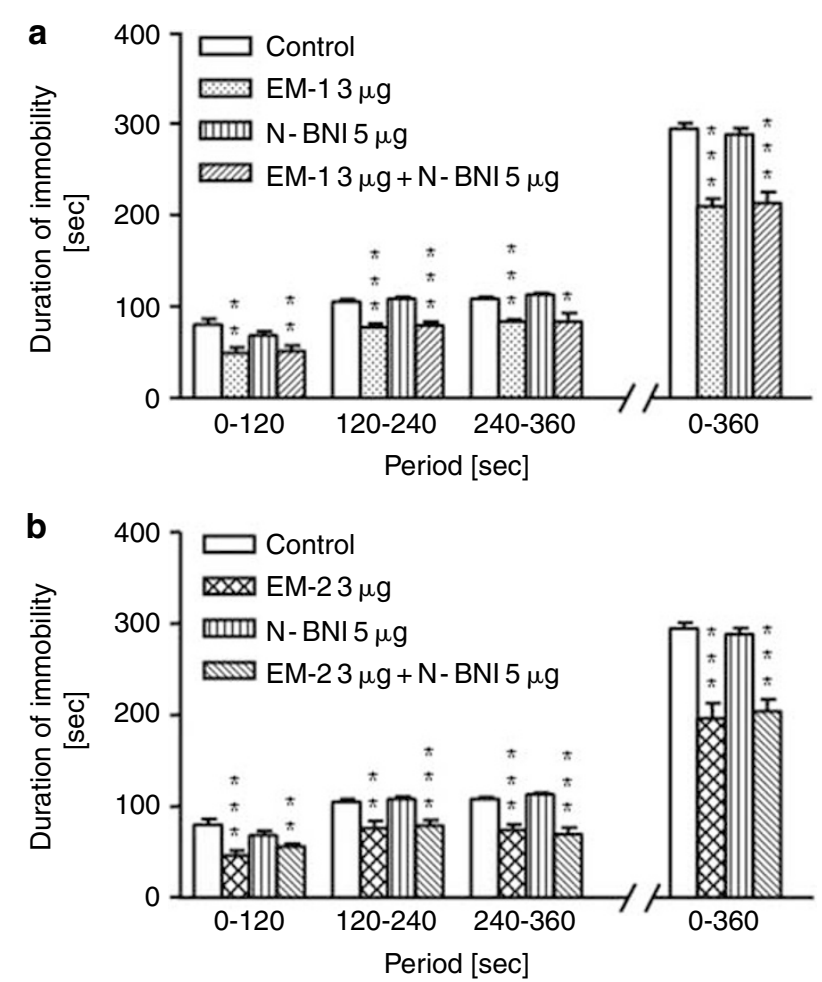

Figure 8 Comparison of the antagonist properties of nor-binaltorphi-

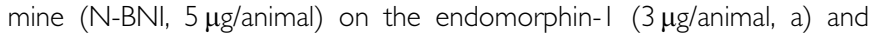
endomorphin-2 ( $3 \mu \mathrm{g} / \mathrm{animal}, \mathrm{b})$-induced effect on the forced-swimming test. Mice were injected i.c.v. and submitted to the swimming test $10 \mathrm{~min}$ after the injection. The duration of immobility was measured during a 6-min period (three consecutive periods of $2 \mathrm{~min}$ each). Data represent mean \pm SEM of 10 mice per group. ${ }^{*} p<0.05$; ${ }^{*} p<<0.0$ I; ${ }^{*} * * * 0.00$ I, as compared to respective control by using two-way ANOVA followed by the Student-Newman-Keuls' test.

data indicate that endomorphins produce a $\mu$-opioid receptor-mediated antidepressant-like activity after i.c.v. administration in mice. Our results suggest that endomorphins and the $\mu$-opioid receptors might play a key role in the physiopathology of depressive disorders, and that the endomorphinergic system could serve as a novel target for the development of antidepressant drugs.

\section{ACKNOWLEDGEMENTS}

This work was supported by a grant from the Conseil Régional de Haute Normandie (to JF), a grant 'Start' from the Foundation for Polish Science (to JF), a grant from the Medical University of Lodz (No 502-11-461), and the support from the Centre National de la Recherche Scientifique (CNRS, France). We wish to thank Jozef Cieslak for his excellent technical assistance.

\section{REFERENCES}

Al-Khrasani M, Elor G, Abbas MY, Ronai AZ (2003). The effect of endomorphins on the release of $3 \mathrm{H}$-norepinephrine from rat nucleus tractus solitarii slices. Reg Pept 111: 97-101.

Asakawa A, Inui A, Momose K, Ueno N, Fujino MA, Kasuga M (1998). Endomorphins have orexigenic and anxiolytic activities in mice. Neuroreport 13: 2265-2267.
Babbini M, Davis WM (1972). Time-dose relationship for locomotor activity effects of morphine after acute or repeated treatment. Br J Pharmacol 46: 213-224.

Belluzi JD, Stein L (1977). Enkephalin may mediate euphoria and drive-reduction reward. Nature 266: 556-558.

Besson A, Privat AM, Eschalier A, Fialip J (1996). Effects of morphine, naloxone and their interaction in the learned helplessness paradigm in rats. Psychopharmacol (Berlin) 123: 71-78.

Bodkin JA, Zornberg GL, Lukas SE, Cole JO (1995). Buprenorphine treatment of refractory depression. J Clin Psychopharmacol 15: 49-57.

Bourin M (1990). Is it possible to predict the activity of a new antidepressant in animals with simple psychopharmacological tests? Fundam Clin Pharmacol 4: 49-64.

Bujdoso E, Jaszberenyi M, Gardi AJ, Foldesi BI, Telegdy G (2003). The involvement of dopamine and nitric oxide in the endocrine and behavioural action of endomorphin-1. Neuroscience 120: 261-268.

Bujdoso E, Jaszberenyi M, Tomboly C, Toth G, Telegdya G (2001). Behavioral and neuroendocrine actions of endomorphin-2. Peptides 22: 1459-1463.

Champion HC, Zadina JE, Kastin AJ, Hackler L, Ge LJ, Kadowitz PJ (1997). Endomorphin 1, and 2, endogenous ligands for the m-opioid receptor, decrease cardiac output, and total peripheral resistance in the rat. Peptides 18: 1393-1397.

Chavkin C, James IF, Goldstein A (1982). Dynorphin is a specific endogenous ligand of the kappa opioid receptor. Science 215: 413-415.

Chen JC, Liang KW, Huang EY (2001). Differential effects of endomorphin-1 and -2 on amphetamine sensitization: neurochemical and behavioral aspects. Synapse 39: 239-248.

Cryan JF, Mombereau C, Vassout A (2005). The tail suspension test as a model for assessing antidepressant activity: review of pharmacological and genetic studies in mice. Neurosci Biobehav Rev 29: 571-625.

Czapla MA, Gozal D, Alea OA, Beckerman RC, Zadina JE (2000). Differential cardiorespiratory effects of endomorphin 1, endomorphin 2, DAMGO, and morphine. Am J Respir Crit Care Med 162: 994-999.

Darko DF, Rich SC, Gilin JC, Golshan S (1992). Association of $\beta$-endorphin with specific clinical symptoms of depression. Am J Psychiatry 149: 1162-1167.

De Witte PH, Heideberg C, Roques PB (1989). Kelatorphan, a potent enkephalinase inhibitor, and opioid receptor agonist DAGO and DTLET, differentially modulate self-stimulation behaviour depending on the site of administration. Neuropharmacology 28: 567-676.

Do-Rego JC, Chatenet D, Orta M-H, Naudin B, Le Cudennec C, Leprince $\mathrm{J}$ et al (2005). Behavioral effects of urotensin-II centrally administered in mice. Psychopharmacology 183: 103-117.

Do-Rego JC, Suaudeau C, Chapouthier G, Costentin J (2002). Mouse lines differing in sensitivity to b-CCM differ in tasks used for testing antidepressants. Pharmacol Biochem Behav 72: 411-416.

Drevets WC (1998). Functional neuroimaging studies of depression: the anatomy of melancholia. Annu Rev Med 49: 341-361.

Drevets WC, Raichle ME (1992). Neuroanatomical circuits in depression: implications for treatment mechanisms. Psychopharmacol Bull 28: 261-274.

Drevets WC, Videen TO, Price JL, Preskorn SH, Carmichael ST, Raichle ME (1992). A functional anatomical study of unipolar depression. J Neurosci 12: 3628-3641.

Duterte-Boucher D, Leclere JF, Panissaud C, Costentin J (1988). Acute effects of direct dopamine agonists in the mouse behavioral despair test. Eur J Pharmacol 154: 185-190.

Eschalier A, Fialip J, Varoquaux O, Makambila MC (1987). Study of the clomipramine-morphine interaction in the forced swimming test in mice. Psychopharmacology 93: 515-519. 
Fichna J, Do-Rego JC, Costentin J, Chung NN, Schiller PW, Kosson $\mathrm{P}$ et al (2004). Opioid receptor binding and in vivo antinociceptive activity of position 3-substituted morphiceptin analogs. Biochem Biophys Res Commun 320: 531-536.

Fichna J, do-Rego JC, Kosson P, Costentin J, Janecka A (2005). Characterization of antinociceptive activity of novel endomorphin-2 and morphiceptin analogs modified in the third position. Biochem Pharmacol 69: 179-185.

Filliol D, Ghozland S, Chluba J, Martin M, Matthes HWD, Simonin $\mathrm{F}$ et al (2000). Mice deficient for $\delta$ - and $\mu$-opioid receptors exhibit opposing alterations of emotional responses. Nat Genet 25: $195-200$.

Huang EYK, Chen CM, Tao PL (2004). Supraspinal anti-allodynic and rewarding effects of endomorphins in rats. Peptides 25: 577-583.

Hughes J, Smith T, Kosterlitz HW, Fothergill LA, Morgan BA, Morris HR (1975). Identification of two related pentapeptides from the brain with potent opiate agonist activity. Nature 258: 577-580.

Hung K, Wu H, Mizoguchi H, Leitermann R, Tseng LF (2003). Intrathecal treatment with 6-hydroxydopamine or 5,7-dihydroxytryptamine blocks the antinociception induced by endomorphin-1 and endomorphin-2 given intracerebroventricularly in the mouse. J Pharmacol Sci 93: 299-306.

Lehmann A (1974). Atlas stéréotaxique du cerveau de la souris. Edition du Centre National de la Recherche Scientifique: Paris.

Li CH, Chung D (1976). Isolation and structure of an untriakontapeptide with opiate activity from camel pituitary glands. Proc Natl Acad Sci USA 73: 1145-1148.

Mansour A, Khachaturian H, Lewis ME, Akil H, Watson SJ (1988). Anatomy of CNS opioid receptors. Trends Neurosci 11: 308-314.

Martin-Schild S, Gerall AA, Kastin AJ, Zadina JE (1999). Differential distribution of endomorphin-1 and endomorphin-2-like immunoreactivities in the CNS of the rodent. J Comp Neurol 405: 450-471.

Pasternak GW (1993). Pharmacological mechanisms of opioid analgesics. Clin Neuropharmacol 16: 1-18.

Petit-Demouliere B, Chenu F, Bourin M (2005). Forced swimming test in mice: a review of antidepressant activity. Psychopharmacol (Berlin) 177: 245-255.

Porsolt RD, Bertin A, Jalfre M (1977). Behavioral despair in mice: a primary screening test for antidepressants. Arch Int Pharmacodyn Ther 229: 327-336.
Schreff M, Schulz S, Wiborny D, Höllt V (1998). Immunofluorescent identification of endomorphin-2-containing nerve fibers and terminals in the rat brain and spinal cord. Neuroreport 9: 1031-1034.

Semba J, Takahashi R (1988). Effect of monoamine precursors on the forced-swimming test in mice. Psychopharmacology 95: 222-225.

Sheline YI (2000). 3D MRI studies of neuroanatomic changes in unipolar major depression: the role of stress and medical comorbidity. Biol Psychiatry 48: 791-800.

Steru L, Chermat R, Thierry B, Mico JA, Lenegre A, Steru M et al (1987). The automated suspension test: a computerized device which differentiates psychotropic drugs. Prog Neuropsychopharmacol Biol Psychiatry 11: 659-671.

Stoll AL, Rueter S (1999). Treatment augmentation with opiates in severe and refractory major depression. Am J Psychiatry 156: 2017.

Sunal R, Gümüsel B, Kayaalp SO (1994). Effect of changes in swimming area on results of behavioral despair test. Pharmacol Biochem Behav 49: 891-896.

Tao R, Auerbach SB (2002). Opioid receptor subtypes differentially modulate serotonin efflux in the rat central nervous system. J Pharmacol Exp Ther 303: 549-556.

Tejedor-Real P, Mico JA, Maldonado R, Roquest BP, Gibert-Rahola $\mathrm{J}$ (1995). Implication of endogenous opioid system in the learned helplessness model of depression. Pharmacol Biochem Behav 52: $145-152$.

Ukai M, Lin HP (2002). Endomorphins 1 and 2 induce amnesia via selective modulation of dopamine receptors in mice. Eur J Pharmacol 446: 97-101.

Vilpoux C, Carpentier C, Leroux-Nicollet I, Naudon L, Costentin J (2002). Differential effects of chronic antidepressant treatments on $\mu$ - and $\delta$-opioid receptors in rat brain. Eur J Pharmacol 443: $85-93$.

Zadina JE (2002). Isolation and distribution of endomorphins in the central nervous system. Jpn J Pharmacol 89: 203-208.

Zadina JE, Hackler L, Ge LG, Kastin AJ (1997). A potent and selective endogenous agonist for the mu opiate receptor. Nature 386: 499-502.

Zadina JE, Martin-Schild S, Gerall AA, Kastin AJ, Hackler L, Ge LJ et al (1999). Endomorphins: novel endogenous m-opiate receptor agonists in the regions of high m-opiate receptor density. Ann NY Acad Sci 897: 136-144. 